OPEN ACCESS

Edited by:

Joanne O'Callaghan,

National Institute of Water and Atmospheric Research (NIWA),

New Zealand

Reviewed by:

Raphael M. Kudela,

University of California, Santa Cruz,

United States

Sabine Schmidt

Centre National de la Recherche

Scientifique (CNRS), France

*Correspondence:

Zhaoru Zhang

zrzhang@sjtu.edu.cn

Meng Zhou

meng.zhou@sjtu.edu.cn

Specialty section: This article was submitted to Coastal Ocean Processes, a section of the journal

Frontiers in Marine Science

Received: 26 July 2020 Accepted: 07 October 2020

Published: 23 October 2020

Citation:

Zhang Z, Zhou M, Zhong Y, Zhang G, Jiang S, Gao Y, Zhang $R$ and Smith WO Jr (2020) Spatial Variations of Phytoplankton Biomass Controlled by River Plume Dynamics Over the Lower Changjiang Estuary and Adjacent Shelf Based on High-Resolution Observations.

Front. Mar. Sci. 7:587539. doi: 10.3389/fmars.2020.587539

\section{Spatial Variations of Phytoplankton Biomass Controlled by River Plume Dynamics Over the Lower Changjiang Estuary and Adjacent Shelf Based on High-Resolution Observations}

Zhaoru Zhang ${ }^{1 *}$, Meng Zhou' ${ }^{*}$, Yisen Zhong', Guosen Zhang', Shan Jiang', Yonghui Gao', Ruifeng Zhang ${ }^{1}$ and Walker O. Smith Jr. ${ }^{1,3}$

${ }^{1}$ School of Oceanography, Shanghai Jiao Tong University, Shanghai, China, ${ }^{2}$ State Key Laboratory of Estuarine and Coastal Research, East China Normal University, Shanghai, China, ${ }^{3}$ Virginia Institute of Marine Science, William \& Mary, Gloucester Point, VA, United States

Phytoplankton biomass in estuarine and continental shelf regions are regulated and modified by physical processes, but these interactions have mostly been investigated at a scale of tens of kilometers, and the role of meso- to sub-mesoscale dynamical processes of freshwater plumes in regulating the spatial and temporal variations of algal biomass is largely unknown. To assess the importance of features at these scales, high-resolution (horizontal spacing $<1 \mathrm{~km}$ ) cross-sectional profiles of hydrographic and biogeochemical variables were collected in the lower Changjiang Estuary and adjacent continental shelf with a towed, undulating vehicle equipped with sensors measuring fluorescence, turbidity and irradiance. Discrete stations were also occupied to allow for the characterization of nutrients. Multiple physical features at different scales regulated the spatial variation of phytoplankton biomass. Phytoplankton biomass was initialized by an improved irradiance field driven by reduced turbidity together with a rapid development of subsurface stratification at the main plume front (isohaline of 23) downstream from the turbidity maximum zone. Phytoplankton blooms did not occur until outcrops located within the main front that were characterized by surface convergence and downwelling, which contributed to large algal biomass by mass trapping and enhanced light penetration. Wave-like features were detected seaward of the main front, coinciding with deacceleration of currents, indicating that they are front-released internal waves that increase algal retention time. This study revealed the critical role of smallscale processes near the plume front in triggering phytoplankton blooms under the large-scale context of improved light conditions, coastal upwelling and nutrient additions from intruding oceanic waters.

Keywords: Changjiang Estuary, phytoplankton biomass, dynamical control, small-scale processes, highresolution observation 


\section{INTRODUCTION}

Estuaries in low to moderate turbidity states and continental shelf regions are biogeochemical hot spots in the world's oceans and major sites of elevated primary production and energy transfer within food webs (Moline et al., 2008; Spahn et al., 2009; Gao et al., 2014; McSweeney et al., 2017). They are recognized as dynamic environments that are controlled by stratification between the fresh and saline waters (for salt-wedge and partially mixed estuaries), energetic mixing in the freshwater plume, and secondary circulations associated with fronts or with complex topography (Wright and Coleman, 1971; Simpson et al., 1990; Chant, 2002; Horner-Devine et al., 2015). Physical processes may influence biogeochemical features as a result of sediment suspension and light availability (Schubel, 1968; Cloern, 1987; Desmit et al., 2005; Xu et al., 2013), nutrient cycling (Moline et al., 2008), and transport of biogenic elements and phytoplankton (Lucas et al., 1999; Geyer et al., 2004; Schofield et al., 2013), and ultimately affect ecosystem production and phytoplankton distributions (Hickey et al., 2010; Cloern et al., 2014).

There are key processes associated with the estuaries that need to be assessed to fully understand the physical control of these complex systems. One such process is the control of estuarine primary productivity and biomass in different zones. Phytoplankton accumulations commonly occur at intermediate salinities on the seaward side of the freshwater plume in nearly all of the world's major rivers (e.g., DeMaster et al., 1996; Lohrenz et al., 1999; Moline et al., 2008; Gao et al., 2014). However, the relationship between the phytoplankton biomass distributions and fresh water plume dynamics is not fully understood. Several physical factors, such as enhancement or inhibition of sediment suspension (Cloern, 1987; DeMaster et al., 1996; Wang et al., 2019), sediment advection (Geyer et al., 2004), tidal stirring (Cloern, 1991), frontal convergence, and secondary circulations (Bai et al., 2015), topographically induced coastal upwelling (Liu and Gan, 2015) and supply of nutrients limiting phytoplankton growth by intruding ocean water masses (Zhang et al., 2007; Tseng et al., 2014) can all affect phytoplankton production and algal growth by modulating light or nutrient availability. These processes occur on different temporal and spatial scales, and the relative dominance of these processes at different locations of the estuary and shelf area determine the spatial variability of phytoplankton production and the associated nutrient cycling. Quantifying the role of these processes from the river mouth to the outer plume area with variations in algal biomass is crucial for understanding the initialization and evolution of phytoplankton blooms.

A number of estuaries have been studied to assess the linkage between physical and biological processes. For example, extensive work has been done on the Hudson River (Fisher et al., 1988; Chant et al., 2008; Jurisa and Chant, 2014), the Mississippi River plumes (Lohrenz et al., 1999, 2008; Guo et al., 2012), and the Changjiang River (Chen et al., 2003; Tseng et al., 2014), all being regions of complex bathymetry and fresh water releases. These studies showed the importance of irradiance, fresh water dynamics, conservative mixing, and biological uptake in regulating the magnitude and location of phytoplankton biomass and growth. However, these studies are mostly based on traditional station measurements and did not address the importance of mesoscale and sub-mesoscale features, and hence may have missed some important processes that contribute to the regulation of algal standing stocks, such as frontal dynamics and wave features.

The Changjiang (Yangtze) River is one of the world's largest rivers, delivering a huge amount of freshwater $\left(\sim 9.24 \times 10^{11} \mathrm{~m}^{3}\right.$ $\mathrm{yr}^{-1}$ ) and nutrients (inorganic nitrogen of $\sim 6.1 \times 10^{10} \mathrm{~mol}$ $\mathrm{yr}^{-1}$ ) into the East China and Yellow Seas (Shen et al., 2003). The freshwater forms an extensive buoyant plume that affects both the dynamical and ecological environments of the coastal and shelf areas of Chinese marginal seas (Chen et al., 2003; Wu et al., 2012; Jiang et al., 2015; Wu, 2015; Zhou et al., 2017). The large inputs of freshwater and nutrients, the presence of a submarine canyon favorable to the generation of mesoscale processes, and close interactions with the Pacific Ocean water via the Kuroshio intrusion makes the Changjiang Estuary a challenging region to study the role of different physical processes in the regulation of phytoplankton growth and accumulation. Physical control on phytoplankton in the Changjiang estuary has been suggested by several studies based on station surveys at a resolution of tens of kilometers and by numerical simulations based on hydrostatic models. These studies attributed phytoplankton blooms to improved light conditions seaward of the estuarine turbidity maxima zone (TMZ) where nutrients are still elevated (Zhu et al., 2009; Wang et al., 2019), to upwelling on the inshore flank of the head of a submarine canyon in the estuary (Pei et al., 2009; Liu and Gan, 2015), or to nutrient supply from the Kuroshio water masses that alleviates phosphorous limitation in the freshwater plume (Tseng et al., 2014; Jiang et al., 2015). Smaller scale processes that are vital to phytoplankton production by inducing accumulation and/or vertical exchange of nutrients, such as plume frontal convergence and mixing and/or internal waves, can neither be resolved by measurements with resolutions greater than $10 \mathrm{~km}$ or reproduced in numerical simulations from hydrostatic models. The only way to reveal the role of such processes in estuarine production is to perform synchronous, high-resolution observations of physical and biogeochemical quantities.

As such, a multidisciplinary research cruise was conducted in the lower Changjiang Estuary and adjacent shelf region in the summer of 2017 (i.e., the flooding season when eutrophication and phytoplankton blooms occur frequently in this area; Chen et al., 2003). Cross-shore profiles of hydrography and biogeochemical variables with a spatial resolution of a few hundred meters to $1 \mathrm{~km}$ were obtained by a towed, undulating vehicle carrying multiple sensors, from which we aim to reveal the coupled physical-biogeochemical processes controlling phytoplankton biomass at meso- to sub-mesoscales.

\section{DATA AND METHODS}

\section{Study Area and Background Information}

The cruise was conducted between 1 and 8 July 2017 in the lower Changjiang Estuary and the adjacent continental shelf of the East 
China Sea (Figure 1A) onboard the R/V Zheyuke II. Synoptic, high-resolution observations of physical and biogeochemical variables were made along two cross-shelf transects (Figure 1B) that extended from two major outlets of the Changjiang river mouth to the offshore regions covered by the Changjiang plume. Transect C1, surveyed during the daytime of July 3, extended from the South Passage of the river mouth to the shelf region. The inshore section of Transect C1 was reoccupied on July 7 during a spring tide, with a focus on the upper water column shallower than $6 \mathrm{~m}$. Transect C2 was surveyed on July 4 and extended from the North Channel of the river mouth offshore to a submarine valley.

\section{Instrumentation, Sampling, and Laboratory Chemical Analyses} Environmental Data

River discharge was measured at the Datong hydrographic Station $630 \mathrm{~km}$ upstream of the survey area (hourly data available at Changjiang Water Resources Commission of the Ministry of Water Resources) ${ }^{1}$. Wind data (speed and direction) were collected by the ship's meteorological station.

${ }^{1}$ http://www.cjw.gov.cn/

\section{High-Resolution Measurements of Coupled Physical-Biogeochemical Parameters}

The coupled physical-biological high-resolution observations were made using a towed, undulating vehicle Acrobat (Sea Sciences Inc., Arlington, MA, United States), which was equipped with an AML MVP-X conductivity-temperature-depth (CTD) sensor package (AML Oceanographic, BC, Canada) and a RBR concerto logger (RBR Ltd., Ottawa, Canada) carrying sensors for colored dissolved organic matter (CDOM), turbidity, photosynthetically available radiation (PAR) and fluorescence. The AML-CTD and RBR logger have sampling frequencies of 25 and $12 \mathrm{~Hz}$ (for all sensors on RBR), respectively, and all parameters were converted to 1-s-average values manually. Fluorescence measurements were converted into chlorophylla (Chl) units in $\mu \mathrm{g} \mathrm{L}^{-1}$ using the manufacturer's calibration, which are used to indicate phytoplankton biomass. During the operation of this Acrobat-Environmental Sensing System (AESS), the ship cruised at a speed of 6 knots. In nearshore areas, the AESS undulated between a depth of 1-2 $\mathrm{m}$ below the surface to 4-5 $\mathrm{m}$ above the sea floor. In offshore areas, it oscillated between 3 and $4 \mathrm{~m}$ below the surface and 30-40 m. The AESS oscillation took from 1 to $2 \mathrm{~min}$ in nearshore waters and 5-6 min in offshore waters, so that the horizontal resolution between 2 successive profiles was 200-400 $\mathrm{m}$ and 1,000 $\mathrm{m}$ in nearshore and

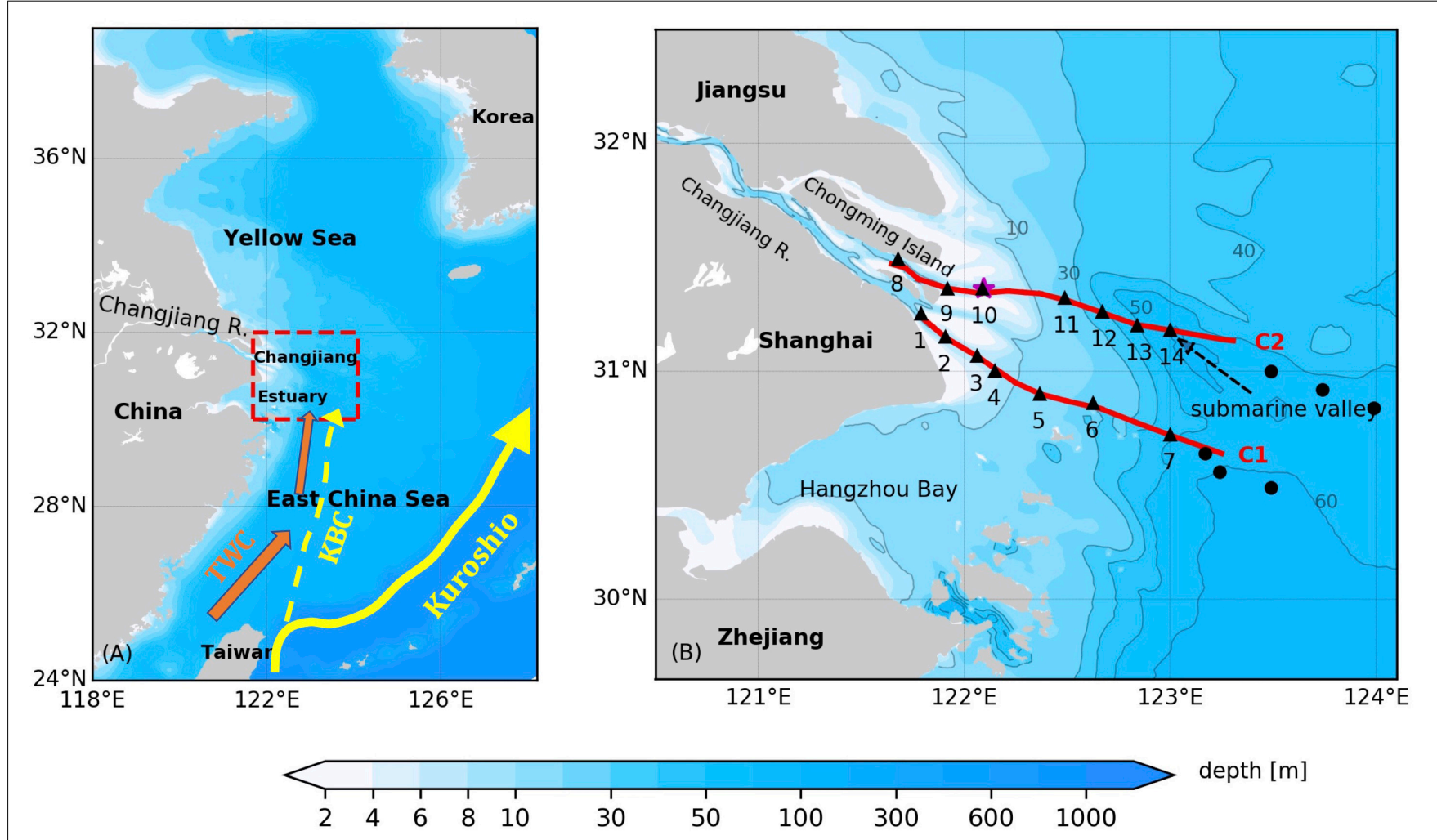

FIGURE 1 | (A) Bathymetry of the East China and Yellow Seas. The Changjiang Estuary and adjacent shelf area that the study is focused on is marked by the red dashed box. The Kuroshio Current, the Kuroshio Branch Current (KBC) and the Taiwan Warm Current (TWC) are indicated in the map. (B) Bathymetry of the study area. The red lines denote the AESS transects surveyed, the black triangles denote CTD stations following the AESS surveys, the black dots denote the CTD stations from the open research cruise, and the purple star denotes the release location of surface drifters. The gray lines are the bathymetry contours of $10 \mathrm{~m}, 30$ $\mathrm{m}, 40 \mathrm{~m}, 50 \mathrm{~m}$ and $60 \mathrm{~m}$. 
offshore areas, respectively. The vertical ascent/descent rate of the AESS was approximately $0.2 \mathrm{~m} \mathrm{~s}^{-1}$.

All sensors on the AESS were calibrated by the manufacturers before the cruise. After the cruise, we also compared measurements from the CDOM, turbidity and fluorescence sensors on the AESS to lab measurements of water samples collected at three stations that were surveyed immediately after AESS surveys (see the details in Supplementary Material). CDOM from these water samples were determined from an Ultraviolet-visible spectrophotometer (Pgeneral TU-1901) from 200 to $800 \mathrm{~nm}$. The absorbance at $350 \mathrm{~nm}$ (a350) was chosen as an index of CDOM abundance. A detailed description can be found in Del Vecchio and Blough (2004). The concentration of the total suspended matter (TSM) was measured by weight. Samples were filtered onto polycarbonate filters, dried and weighed on a Cahn electrobalance. Chlorophyll concentrations were determined after $90 \%$ acetone extraction for $24 \mathrm{~h}$ in a refrigerator and calculated by the trichromatic method (Parsons et al., 1984) using a Hitachi spectrophotometer (F-2700). The laboratory values of CDOM, TSM, and Chl concentrations and the relevant variables generated by the sensors were all significantly correlated $(r>0.9, p<0.05$; see the comparison in Supplementary Table S1), giving us the confidence that the AESS accurately captured the spatial variations of these parameters. The Chl concentrations measured by AESS were calibrated by the lab-analyzed $\mathrm{Chl}$ values using the linear regression method (see Supplementary Table S1).

\section{Underway Surface Dissolved Oxygen (DO) Measurements}

An optode sensor (Anderra 4531) was installed about $50 \mathrm{~m}$ from underway water intake of the research vessel. To minimize the oxygen consumption during the water flow, the water line was bleached for $30 \mathrm{~min}$ and washed thoroughly prior to the cruise. The optode continuously measured the oxygen concentrations in water pumped from $5 \mathrm{~m}$, with a sampling frequency of $15 \mathrm{~s}$. This oxygen sensor was calibrated before deployment, and the measurements were then compared with discrete DO samples from the same water source during the cruise using the Winkler titration method.

\section{Nutrient Sampling and Analyses}

Each AESS survey was immediately followed by occupation of stations spaced at a relatively coarse resolution of tens of kilometers. At each station, water samples were collected at 2-4 depths using a CTD-rosette sampler equipped with 12 $12 \mathrm{~L}$ Niskin bottles. A fraction of water was filtered through a polycarbonate membrane (pore size: $0.4 \mu \mathrm{m}$, Whatman ${ }^{\circledR}$ ) to quantify the concentrations of dissolved inorganic nitrogen $\left(\mathrm{DIN} ; \mathrm{DIN}=\mathrm{NO}_{3}^{-}+\mathrm{NO}_{2}^{-}+\mathrm{NH}_{4}^{+}\right)$, phosphate (DIP) and silicate $\left[\mathrm{Si}(\mathrm{OH})_{4}\right]$. The filtrate was frozen at $-20^{\circ} \mathrm{C}$, and nutrient concentrations were determined by a flow injection analyzer (Skalar Analytical B.V., Netherlands) using standard colorimetric procedures (Hansen and Koroleff, 1999), with the analytical accuracy $\leq 3 \%$. Nutrients in the surface layer (from 3.5 to $5 \mathrm{~m}$ ) at 7 stations on both Transect $\mathrm{C} 1, \mathrm{C} 2$ (Figure 1B) were used to explore the relationship between nutrient concentrations and coupled physical-biological processes. When investigating nutrient variations along salinity gradient, we also employed data from 6 stations in the outer plume area from a cruise which was surveyed from 27 July 2017 to 2 August 2017 (Figure 1B). While the cruise was conducted about 3 weeks after our main cruise, previous studies demonstrated that the nutrient:salinity ratio in the Changjiang Estuary and adjacent shelf are relatively stable over the timescale of a few weeks in summer (Zhang et al., 2007), making it reasonable for us to use the nutrient data from the cruise as the oceanic end member. The nutrient data from the cruise were analyzed in a similar manner to those described above.

\section{Surface Drifters}

Five Davis drifters (Davis, 1985) were released for tracking surface freshwater movement. The drifters were released at 10:00 on 5 July 2017 seaward of the North Channel of the Changjiang Estuary (Figure 1B). The Davis drifters were equipped with GPS receivers and Iridium-based satellite telemetry, and the drifter locations were sent hourly. As the plume thickness was between 5 and $10 \mathrm{~m}$, the drogue center of the drifters was set at $2.5 \mathrm{~m}$ to track the plume spreading trajectory, the surface velocity and the retention time of the plume water.

\section{Physical Indices}

Stratification was quantified by the stratification frequency $N^{2}$, which is given by:

$$
N^{2}=-\frac{g}{\rho_{0}} \frac{\partial \rho}{\partial z},
$$

where $g$ is the gravitational acceleration constant $\left(9.8 \mathrm{~m} \mathrm{~s}^{-2}\right), \rho$ is density, $\rho_{0}$ is the mean density (taken as $1,020 \mathrm{~kg} \mathrm{~m}^{-3}$ ), and $z$ is the vertical axis (Cushman-Roison and Beckers, 2011). Larger $N^{2}$ values denote larger vertical gradient of density and thus stronger stratification.

The flow state is indicated by the Froude number Fr, which is given by:

$$
F r=u / \sqrt{g^{\prime} h}
$$

where $u$ is the flow speed, $g^{\prime}$ is the reduced gravity, and $h$ is the surface layer thickness above the maximum stratification of the water column (Farmer and Armi, 1986). $g^{\prime}$ is given by $g^{\prime}=g \Delta \rho / \rho_{0}$, where $\Delta \rho$ is the density difference between the two layers above and below the stratification interface. $F r>1$ implies that the flow is in a supercritical, energetic state, and Fr $<1$ implies that the flow is in a subcritical, less energetic state due to energy release.

\section{RESULTS}

\section{The South Passage Phytoplankton Biomass in Well-Mixed and Stratified Zones Near the River Mouth}

Large gradients of temperature, salinity, density and CDOM were observed along Transect C1 (Figures 2A-C,E), with salinity 

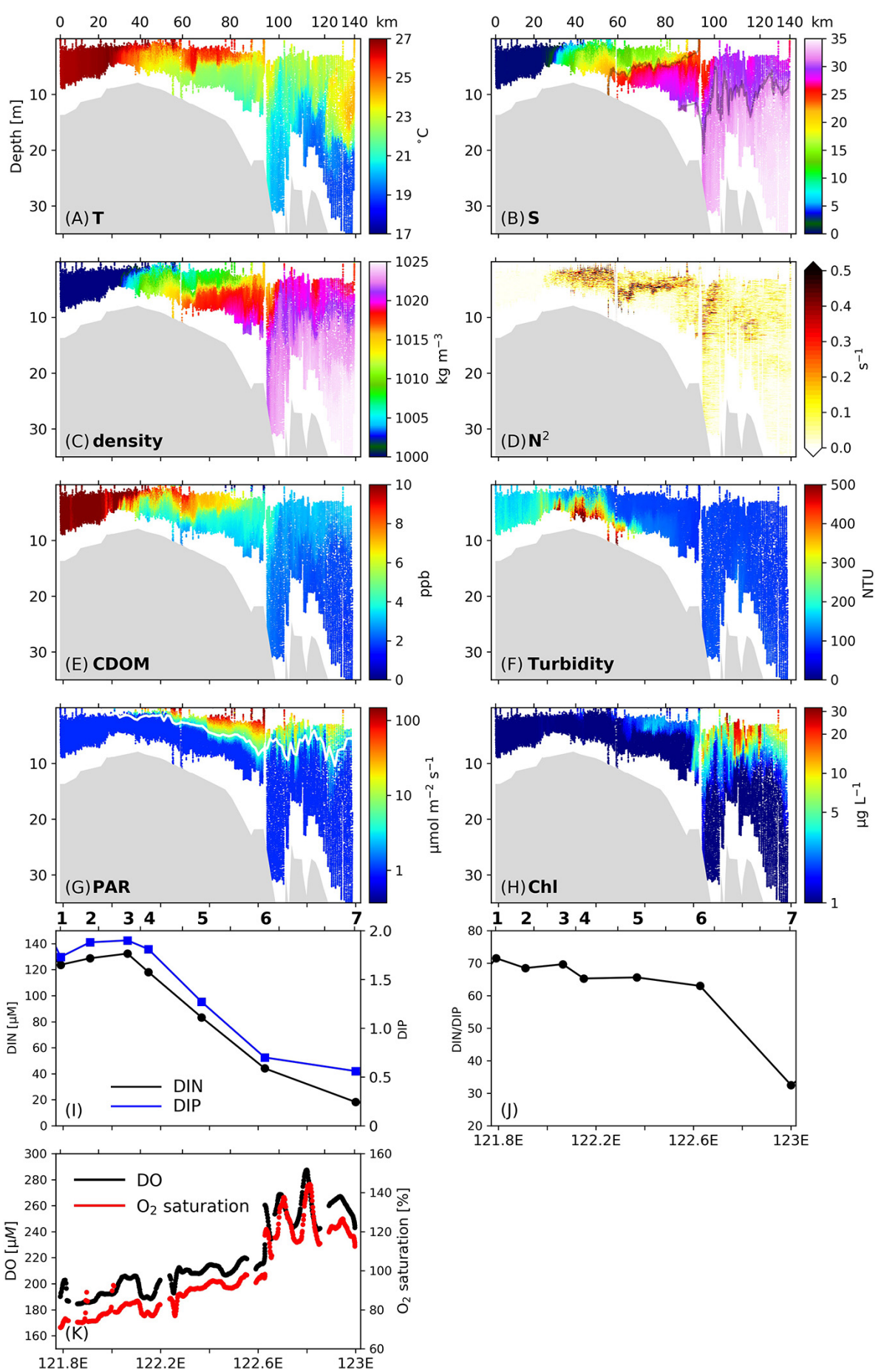

FIGURE 2 | (A-G) Vertical profiles of (A) temperature, (B) salinity, (C) density, (D) stratification frequency ( $\left.N^{2}\right)$, (E) CDOM concentrations, (F) turbidity, (G) PAR, and (H) Chl concentrations along Transect C1 surveyed on 3 July 2017. Numbers on the upper $x$-axis denotes the distance (unit: km) from the inshore boundary of the transect. Isohalines of 23 and 31 are denoted by the gray lines in (B). The white line in (G) denotes the euphotic layer depth. (I) Surface DIN (black line) and DIP (blue line) concentrations along C1. (J) Surface ratio of DIN to DIP along C1. (K) Surface dissolved oxygen (DO) concentrations (black dots) and oxygen saturation (red dots) along C1. Stations are labeled on top of $(\mathbf{I}, \mathbf{J})$.

increasing and $\mathrm{CDOM}$ generally decreasing from the river to the shelf region, respectively. A series of salt wedges indicated by large salinity gradients were detected in the salinity profiles, and the spatial pattern of CDOM was similar to that of salinity. The profile of stratification frequency reveals strong vertical mixing, as indicated by low $N^{2}$ values $\left(<0.01 \mathrm{~s}^{-1}\right)$ in the salinity 
range of $0-5$. In the salinity range of $5-15\left(122.1-122.25^{\circ} \mathrm{E}, 30-\right.$ $60 \mathrm{~km}$ away from the inshore boundary of $\mathrm{C} 1$ ), stratification developed at the surface due to the thermal, salt and density fronts, and $N^{2}$ exceeded $0.5 \mathrm{~s}^{-1}$. In this area, $N^{2}$ values below 5 $\mathrm{m}$ remained below $0.1 \mathrm{~s}^{-1}$, indicating energetic vertical mixing in the deep layers. CDOM in the freshwater layer was diluted by being mixed with low-CDOM oceanic water, confirming the extensive vertical mixing. Turbidity (Figure $2 \mathrm{~F}$ ) in the subsurface layers reached maximum values in the estuarine region (300-400 NTU) denoting the existence of an estuarine TMZ. Sediments in the lower portion of the water column were resuspended by interaction with the sea floor and the strong vertical mixing, and extended to $2 \mathrm{~m}$, where further upward penetration was inhibited by the surface stratification. In this area surface PAR values (Figure 2G) increased from nearly zero to 5-100 $\mu \mathrm{mol}$ $\mathrm{m}^{-2} \mathrm{~s}^{-1}$, while the Chl values did not change significantly.

Further offshore and in the salinity range of 15-30 (122.25$122.6^{\circ} \mathrm{E}, 50-90 \mathrm{~km}$ ), a notable salt wedge appeared near the isohaline surface of 23 , followed by a sharp density front at the isopycnal surface of $1,015 \mathrm{~kg} \mathrm{~m}^{-3}$. Large $N^{2}$ values were concentrated in a narrow band, suggesting that this is the main front of the Changjiang river plume. The 23-isohaline has also been noted as an indicator for the main front of the Changjiang plume in summer in previous work (Xuan et al., 2012). The stratification associated with this subsurface front effectively confined resuspended sediments below $5 \mathrm{~m}$, and the decreased sediment concentrations in the upper layer led to an immediate increase in in situ PAR as well as a deepening of the euphotic zone, which is calculated as the depth where the PAR value equals $1 \%$ of the surface PAR value, from $2 \mathrm{~m}$ to $5-7 \mathrm{~m}$. With high concentrations of nutrients delivered in the river runoff (ca. 132.3 $\mu \mathrm{M}$ and $1.9 \mu \mathrm{M}$ for DIN and DIP, respectively, Figure 2I) at the inshore boundary of this area, together with significantly improved light conditions, $\mathrm{Chl}$ in the surface layer began to increase and reached $4 \mu \mathrm{g} \mathrm{L}^{-1}$. The surface DO values increased from 200 to $220 \mu \mathrm{M}$ (Figure 2J), and oxygen saturation increased from 80 to $95 \%$. At the offshore boundary of this stratified zone, the DIN concentration had dropped to $44.1 \mu \mathrm{M}$, while the ratio of DIN to DIP (DIN/DIP) did not noticeably change (Figure 2J).

\section{Phytoplankton Accumulation at the Plume Surface Front}

In the region between $122.6^{\circ} \mathrm{E}$ and $122.7^{\circ} \mathrm{E}(90-100 \mathrm{~km})$ where the 23-isohaline outcropped at the surface (i.e., the surface front location, Figure 2B), a headwave structure characterized by downwelling and vertical mixing (Kilcher and Nash, 2010) was observed. This headwave had a horizontal length scale of approximately $10 \mathrm{~km}$. The downwelling was reflected by the depression of the 31-isohaline that represents the base of the freshwater plume (Lie et al., 2003) from 13 to nearly $20 \mathrm{~m}$. Downwelling is also clearly observed in the temperature and density profiles by the depression of isotherms and isopycnals at the surface front. Such downwelling led to a further decrease in sediment concentrations in the mid-water column due to a lack of sediment resuspension (Figure 2F), and within the layer between 5 and $10 \mathrm{~m}$, turbidity decreased from $120 \mathrm{NTU}$ in the stratified zone to below $100 \mathrm{NTU}$ in the frontal zone, and then increased slightly further offshore. The decrease in sediment concentration was followed by a noticeable increase in the euphotic layer depth to $10 \mathrm{~m}$ (Figure 2G). The frontal vertical mixing was reflected by the signals of high-temperatures (above $21^{\circ} \mathrm{C}$, Figure $2 \mathrm{~A}$ ) and low-salinities (below 32, Figure $2 \mathrm{~B}$ ) reaching the bottom. At the bottom of the frontal region, the temperature and salinity values were still greater and lower than those in ambient waters by $0.5^{\circ} \mathrm{C}$ and 1 .

At this front location, the $\mathrm{Chl}$ concentrations at the surface increased sharply from $4 \mu \mathrm{g} \mathrm{L}^{-1}$ to $10-20 \mu \mathrm{g} \mathrm{L}^{-1}$, denoting the existence of phytoplankton blooms. The change in Chl was accompanied by a rapid increase in the surface DO concentration from 207 to $270 \mu \mathrm{M}$, and an increase in oxygen saturation from 95 to $120 \%$. These signals together indicate active phytoplankton growth at the front. Within the zone of strong downwelling and vertical mixing, Chl concentrations above $15 \mu \mathrm{g} \mathrm{L}^{-1}$ penetrated to about $10 \mathrm{~m}$, and $\mathrm{Chl}$ concentrations of $2-3 \mu \mathrm{g} \mathrm{L}^{-1}$ were observed in waters deeper than $15 \mathrm{~m}$.

In addition to the frontal headwave structure, immediately seaward of the main surface front, a series of pulses featured by high temperature, low salinity and high CDOM concentrations were observed in the area from $122.7^{\circ} \mathrm{E}$ to $122.9^{\circ} \mathrm{E}(100-120 \mathrm{~km})$. These wave-like features were characterized by a spatial scale of $3-5 \mathrm{~km}$, and caused a $10 \mathrm{~m}$ undulation of the plume base. Those patterns are also clearly visible in the $\mathrm{Chl}$ field as indicated by the pulse-like plunging of surface high-Chl signals. In this area, the Chl concentrations in the upper $10 \mathrm{~m}$ were increased by 10-20 $\mu \mathrm{g} \mathrm{L}^{-1}$ relative to those of surrounding waters. The undulating signatures were also imprinted in the surface DO and oxygen saturation fields. The DO concentration in the zone of 122.6$122.9^{\circ} \mathrm{E}$ oscillated between 240 and $290 \mu \mathrm{M}$ in a wavelike pattern with a length scale of $3-5 \mathrm{~km}$, and the oxygen saturation in this area oscillated between 120 and $150 \%$ in a similar way.

\section{Spatial Distributions of the Physical and Biogeochemical Variables During a Spring Tide Survey}

The spatial patterns of hydrographic and biogeochemical variables re-surveyed on the inshore section of $\mathrm{C} 1$ on July 7 were compared to the patterns on July 3 in the same section (Figure 3). The freshwater fronts in the salinity range of $0-15$ had moved considerably seaward on July 7 compared to those on July 3 (Figures $\mathbf{3 A}, \mathbf{B}$ ), while the location of the TMZ did not change significantly (Figures 3G,H). On July 7, stratification west of $122.3^{\circ} \mathrm{E}$ became weaker (Figure 3D vs. Figure 3C) under the spring tide associated with stronger mixing, and as a consequence the sediment concentrations in the upper water column of the TMZ were much larger compared to those on July 3.

While information of stratification was missing in the hydrographic distributions on July 7 due to the shallow depth range covered by the AESS measurements, the light fields (Figures 3I,J) showed that irradiance significantly increased in the upper water column at nearly the same location $\left(122.2^{\circ} \mathrm{E}\right)$ on July 3 and July 7 , indicating similar locations where strong subsurface stratification associated with the main plume front began to develop. Correspondingly, increases in 


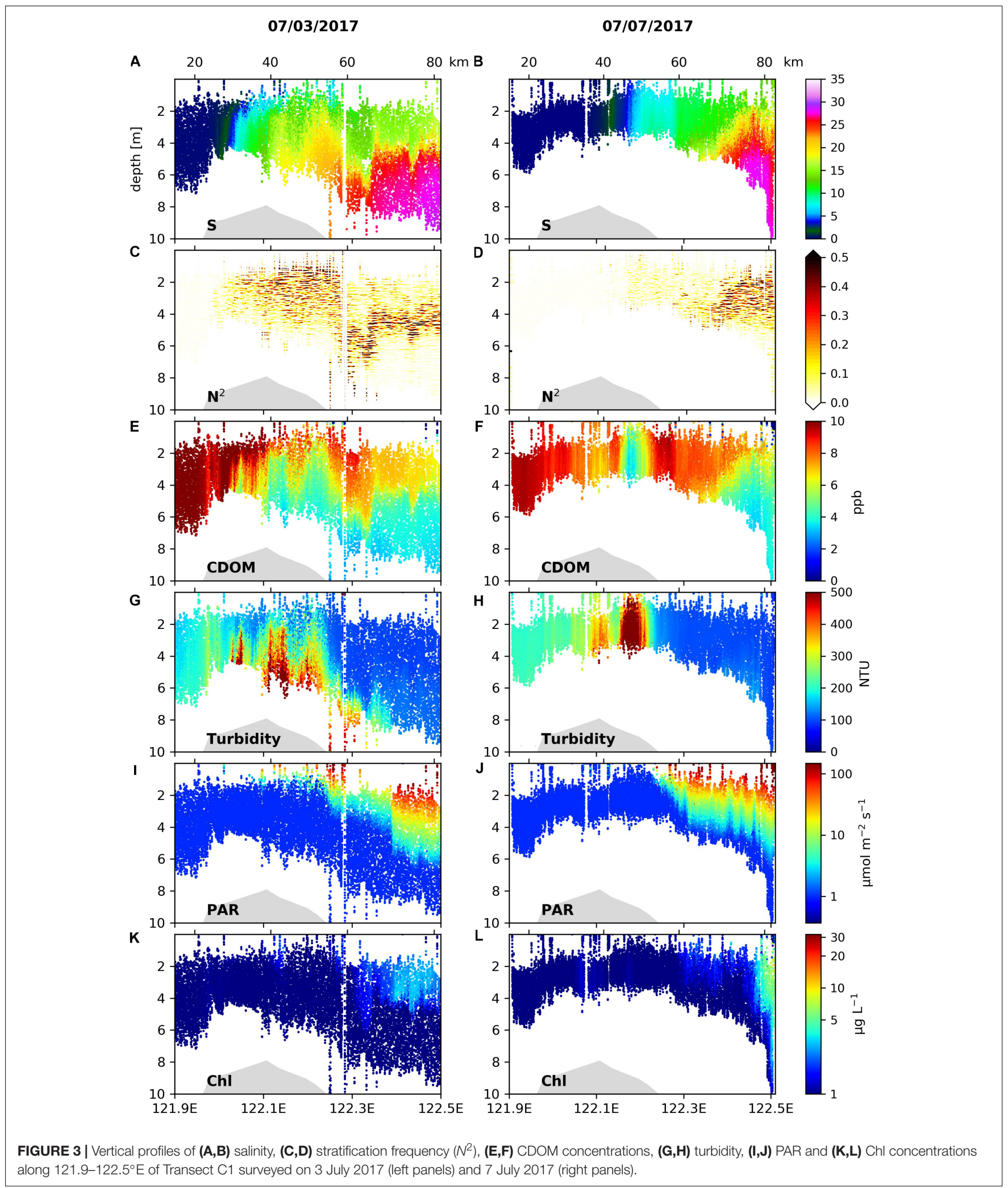

Chl concentrations under improved light conditions during the two surveys appeared at similar locations (Figures $3 \mathbf{K}, \mathbf{L}$ ). On July 7 , the Chl increase accompanying the strengthening in stratification was less than that on July 3. On July 7, near $122.5^{\circ} \mathrm{E}$ the $\mathrm{Chl}$ concentration in the surface layer increased from 2 to $5-10 \mu \mathrm{g} \mathrm{L}^{-1}$, and there was a downward penetration 
of high Chl concentrations to $\sim 10 \mathrm{~m}$ following downward depression of isotherms (Figure 3B) and isohalines (Figure 3D), indicating the existence of the surface plume front characterized by downwelling and vertical mixing. The location of this front was shifted landward by approximately $20 \mathrm{~km}$ relative to that on July 3 .

\section{The North Channel \\ Coupled Physical-Biogeochemical Processes in the Well Mixed and Stratified Zones}

The relationships between mixing/stratification and phytoplankton production were also found on Transect C2 (Figure 4), with some differences from Transect C1. Energetic vertical mixing indicated by vertically uniform temperatures, salinities, densities, CDOM concentrations, and low $\mathrm{N}^{2}$ below $0.01 \mathrm{~s}^{-1}$ (Figures 4A-E) occurred inshore of $122^{\circ} \mathrm{E}$ (ca. $35 \mathrm{~km}$ from the inshore boundary of $\mathrm{C} 2$ ). As a result, resuspended sediments penetrated to the surface and created a TMZ on this transect (Figure 4F), while the turbidity values in the subsurface layers (150-300 NTU) were less than those in the TMZ of Transect C1 (300-500 NTU).

The development of stratification started at $\sim 122^{\circ} \mathrm{E}(35 \mathrm{~km})$, where intrusion of saline water with salinity above 10 was detected near the bottom, and $N^{2}$ increased above $0.2 \mathrm{~s}^{-1}$ in the mid-water column. Sediments were confined below the stratification interface and the surface turbidity was reduced to 100-150 NTU. The stratification was strengthened between $122.2^{\circ} \mathrm{E}$ and $122.7^{\circ} \mathrm{E}(60-120 \mathrm{~km})$. The enhanced subsurface stratification was accompanied by a slight increase in the penetration of PAR (Figure 4G). Unlike $\mathrm{C} 1$, within $\mathrm{C} 2$ a noticeable increase in phytoplankton biomass at the onset of strong stratification was not observed, and Chl concentrations remained near $1 \mu \mathrm{g} \mathrm{L}^{-1}$ between $122^{\circ} \mathrm{E}$ and $122.5^{\circ} \mathrm{E}(35-85 \mathrm{~km}$, Figure 4H). The surface DIN concentration decreased from 103.5 $\mu \mathrm{M}$ at $122.1^{\circ} \mathrm{E}$ to $70.5 \mu \mathrm{M}$ at $122.5^{\circ} \mathrm{E}$ (Figure $4 \mathrm{I}$ ), and the DIP concentration decreased from 1.40 to $0.29 \mu \mathrm{M}$ in this zone. The DIN/DIP value showed only a slight decrease (Figure 4J). There was no significant change in the surface DO concentration or oxygen saturation in this area (Figure $4 \mathrm{~K}$ ).

An upwelling feature existed on the western flank of the submarine valley (i.e., between 122.4 and $123^{\circ} \mathrm{E}, 70-130 \mathrm{~km}$ ) indicated by the doming of the isotherm $20.5^{\circ} \mathrm{C}$. Seaward of $122.5^{\circ} \mathrm{E}$ in the upwelling zone, the surface $\mathrm{Chl}$ concentration showed a sharp increase from $\sim 1$ to $>20 \mu \mathrm{g} \mathrm{L}^{-1}$. This location coincided with where vertical mixing developed at the base of the plume, which spanned from 122.5 to $123^{\circ} \mathrm{E}(85-130 \mathrm{~km})$. The vertical mixing was identified in the salinity and density fields, but was most notable in the CDOM profile as reflected by the penetration of high-CDOM signals into the oceanic water of 15$25 \mathrm{~m}$. The rapid increase in phytoplankton biomass was followed by a sharp increase in the surface DO concentration from 200 to $450 \mu \mathrm{M}$, and an increase in oxygen saturation from $<100 \%$ to above $200 \%$. Surface DIN concentrations decreased from 70.5 to $22.9 \mu \mathrm{M}$, while the DIN/DIP value dramatically changed, increasing from 58 to 140 in $122.5-122.9^{\circ} \mathrm{E}$ and then declining to 55 at $123^{\circ} \mathrm{E}$.

\section{The Surface Plume Front and Phytoplankton Accumulation}

On Transect C2, the surface plume front accompanied by downwelling occurred at $122.9-123.1^{\circ} \mathrm{E}(125-150 \mathrm{~km})$ as revealed from the hydrography fields (Figures $4 \mathrm{~A}-\mathrm{C}$ ), and the wide horizontal span of the downwelling indicates a more diffuse front (over $25 \mathrm{~km}$ ) compared to $\mathrm{C} 1(10 \mathrm{~km})$. The downwelling reached a depth of $8 \mathrm{~m}$, carrying high-Chl concentrations ( $>10$ $\mu \mathrm{g} \mathrm{L}^{-1}$ ) to this depth (Figure $4 \mathbf{H}$ ). Deep vertical mixing at the front was indicated by a depression of isotherms, isohalines and isopycnals between 25 and $35 \mathrm{~m}$. Large phytoplankton biomass was present at the surface of the frontal region, where surface DO concentrations and oxygen saturations reached their maxima within Transect C2 (450 $\mu \mathrm{M}$ and 250\%, respectively), and DIN concentrations reached their minima $(22.9 \mu \mathrm{M})$.

\section{Phytoplankton Biomass Influenced by Oceanic Water Masses}

Seaward of $123^{\circ} \mathrm{E}(135 \mathrm{~km})$ on $\mathrm{C} 2$, a water mass with high temperatures and salinities was observed (Figures $4 \mathrm{~A}, \mathbf{B}$ ). The temperature and salinity ranges were $20.5-24.5^{\circ} \mathrm{C}$ and $33-$ 34.2 , respectively, and resembled the characteristics of Taiwan Warm Current Surface Water (TWCSW) that originates from a mixture of Kuroshio surface water and the Taiwan Strait water that intrudes into the Changjiang Estuary (Tang and Wang, 2004; Zhang et al., 2014). The TWCSW was delineated by the $21^{\circ} \mathrm{C}$ isotherm from the deeper Taiwan Warm Current Deep Water (TWCDW) (Figure 4A) originating from the Kuroshio subsurface water (Zhang et al., 2014). The temperature-salinity characteristics reveal that the upwelled water in $122.4-123^{\circ} \mathrm{E}$ originates from TWCDW (Figure 5). TWCDW is a nutrient-rich water mass with low nitrate to phosphate (N/P) ratios compared to the Changjiang plume water (Zhang et al., 2007; Yang et al., 2013). The DIN/DIP ratio on C2 exceeded 125 between $122.5^{\circ}$ and $122.9^{\circ} \mathrm{E}$, and decreased to 54 offshore of $122.9^{\circ} \mathrm{E}$ where TWCDW occurred at depth, indicating the role of the TWCDW entrainment in reducing the DIN/DIP value in plume water. The alleviation in phosphorous stress corresponded with high phytoplankton biomass in both the surface and subsurface layers.

\section{The Dispersion and Retention Time of Plume Water From Drifter Measurements}

The five surface drifters were released seaward of the TMZ on C2 (see Figure 4F). Most drifters traveled northeastward (Figure 6), the typical dispersion path of the Changjiang river plume in summer. The drift paths can be classified into three groups. Drifters D3 and D5 drifted northward near the river mouth and then northeastward, whereas Drifters D1 and D2 initially drifted southward for 2-3 days and then turned northeast. Drifter D4 moved southeastward to $30^{\circ} \mathrm{N}$ during the first 10 days and then moved to northeast under the influence of shelf currents.

The drifter-derived retention times of the Changiiang plume water west of $124^{\circ} \mathrm{E}$, the area of major algal blooms in the Changjiang river delta (Jiang et al., 2015), were from 5-6 days when they move directly northeastward (like Drifters D3 and D5), $\sim 10$ days when they drift like Drifters D1 and D2, and 

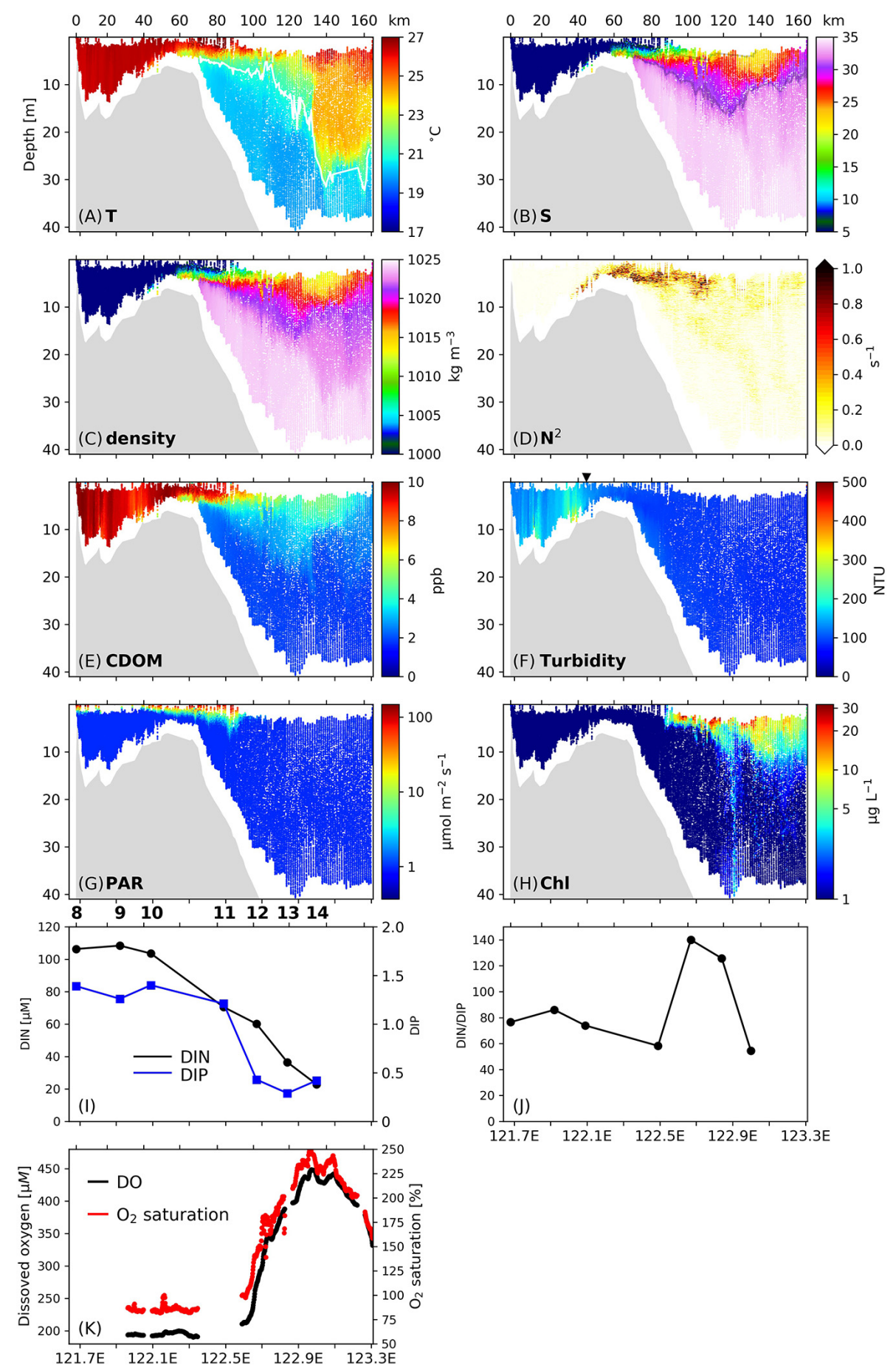

FIGURE 4 | (A-G) Vertical profiles of (A) temperature, (B) salinity, (C) density, (D) stratification frequency ( $\left.N^{2}\right)$, (E) CDOM concentrations, (F) turbidity, (G) PAR and (H) Chl concentrations along Transect C2. Numbers on the upper $x$-axis denotes the distance (unit: $\mathrm{km}$ ) from the inshore boundary of the transect. The isotherm of $21^{\circ} \mathrm{C}$ is denoted by the white line in (A), and isohalines of 23 and 31 are denoted by the gray lines in (B). The triangle above (F) labels the release location of the surface drifters. (I) Surface DIN (black line) and DIP (blue line) concentrations along C2. (J) Surface ratio of DIN to DIP along C2. (K) Surface dissolved oxygen (DO) concentrations (black dots) and oxygen saturation (red dots) along C2. Stations are labeled on top of $(\mathbf{I}, \mathbf{J})$.

$\sim 18$ days if they move southwestward to Hangzhou Bay and then turn northeast (Drifter D4). For Drifters D1, D2, D3, and D5, west of $122.5^{\circ} \mathrm{E}$ the surface velocity stayed mostly above $1.2 \mathrm{~m}$ $\mathrm{s}^{-1}$ during ebb tides, varying between 1.0 and $1.7 \mathrm{~m} \mathrm{~s}^{-1}$. Offshore of $122.5^{\circ} \mathrm{E}$, the velocity during ebb tides decreased to less than $0.8 \mathrm{~m} \mathrm{~s}^{-1}$. 


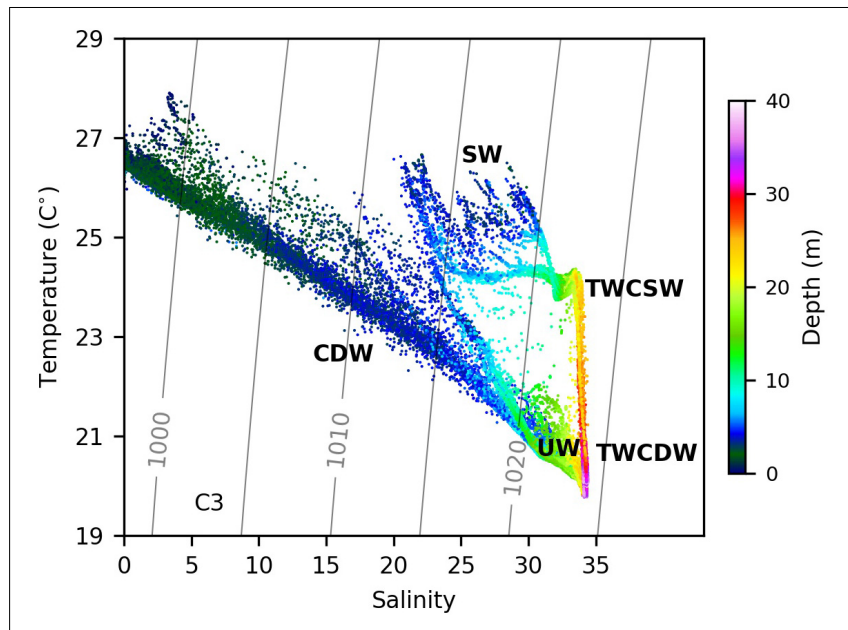

FIGURE 5 | The temperature-salinity diagram from measurements on Transect C2. CDW, TWCSW, TWCDW, UW, and SW denote the Changjiang diluted water (or the plume water), the Taiwan Warm Current surface water, the Taiwan Warm Current deep water, the upwelled water and the ambient surface water, respectively. Color represents the depth of each measured point.

\section{DISCUSSION}

\section{The Relative Importance of Mixing and Biological Consumption on Cross-Shelf Nutrient Gradients}

On Transect C1, dramatic decreases in nutrient concentrations were observed in the strongly stratified zone created by the subsurface plume front $\left(122.2-122.6^{\circ} \mathrm{E}\right.$, Figure 2), where DIN and DIP were reduced by 88.2 and $1.1 \mu \mathrm{M}$, respectively. This area is also where phytoplankton biomass was elevated with improved light conditions under low turbidity. The contribution of biological consumption to the nutrient reduction was estimated by the ratio of $\mathrm{Chl}$ to $\mathrm{C}(\mathrm{Chl} / \mathrm{C})$ and the Redfield stoichiometry. The Chl concentration in this region was $2.0-4.0 \mu \mathrm{g} \mathrm{L}^{-1}$, yielding a phytoplankton carbon biomass of $6.0-12.0 \mu \mathrm{M}$ based on a $\mathrm{Chl} / \mathrm{C}$ ratio of 30 for the Changjiang plume water in summer (Liu et al., 2019). The estimated consumption of DIN and DIP from the Redfield stoichiometry (106:16:1 for C:N:P) was, respectively, $0.91-1.81$ and $0.06-0.11 \mu \mathrm{M}$, much smaller than the observed reduction in DIN and DIP in this strongly stratified zone. This indicates that the large nutrient gradient in this area was not solely created by biological production, but mostly from mixing between the plume water and oceanic water, similar to other estuarine plumes (Fisher et al., 1988; Lohrenz et al., 1999). The variations of DIN with salinity on $\mathrm{C} 1$ (Figure 7A) showed that in the surface salinity range of 10-25 corresponding to the zone of strong stratification, DIN concentrations were above the conservative mixing line, indicating the addition of DIN, possibly from regeneration from suspended sediments (Figure 7D; Jiang et al., 2020). Nutrient regeneration, resulting from decomposition of organic debris, can also be inferred from CDOM that remained above the mixing line in this salinity range (Figure 7E), as mineralization of organic matter also produces marine-derived CDOM (Lefèvre et al., 2017). The variation of DIN followed the conservative mixing line, suggesting that the lateral gradient of DIN was primarily driven by mixing. The $\mathrm{Si}(\mathrm{OH})_{4}$ concentration (Figure 7B) fell directly on the conservative mixing line, indicating the stability of the nutrient-to-salinity ratio over the time period between the two cruises. The DIN/DIP ratio was constant in this salinity range (Figure 7C), again suggesting that biological activities did not dominate nutrient reductions. These results further suggest that the improved light field with reduced turbidity cannot immediately promote phytoplankton production and algal blooms, as time is required for phytoplankton growth and accumulation.

On Transect C2, within the salinity range of $0-17$ corresponding to the sampling area of $121.7-122.5^{\circ} \mathrm{E}$, the variation of DIN (Figure 8A) and $\mathrm{Si}(\mathrm{OH})_{4}$ (Figure 8B) concentrations with salinity fell onto the conservative mixing line, indicating that the nutrient reduction in this zone was mainly a result of physical mixing; the noticeable reduction of DIN/DIP in the salinity range of 3-15 from 74 (at station 10) to 58 (at station 11) (Figure 8C) suggests the role of upwelling (see Figure 4) in supplying phosphate into the plume water. In the salinity range of 20-25 (corresponding to station 12 and 13 that are still in the upwelling region), the DIN concentrations fell below the conservative mixing line, accompanied by a dramatic increase in the DIN/DIP value. This indicates the initialization of primary productivity by the combined effects of upwelling and vertical mixing, and the active biological activities could accelerate the utilization of DIP, although phosphate can be supplied from the upwelled water (Tseng et al., 2014). This salinity range does not exactly correspond to the range where the maximum $\mathrm{Chl}$ concentrations were observed (Figure 8D), possibly due to the fact that the station sampling for nutrients were conducted after the AESS measurements for the entire C2 transect were completed, and there was temporal and spatial variation of phytoplankton distribution related to the plume dispersion. At station 14 the DIN/DIP value dropped to 54, suggesting that the phytoplankton accumulation in this area (Figure 4H) was mainly a result of physical processes such as frontal convergence rather than active algal growth.

\section{Convergence at the Main Plume Front and Its Impact on Algal Biomass}

On C1, a sudden increase in Chl concentrations to $10-20 \mu \mathrm{g}$ $\mathrm{L}^{-1}$ was observed at the front location near $122.6^{\circ} \mathrm{E}$ (Figure $2 \mathrm{H}$ ). The observed downwelling and vertical mixing was a result of convergence at the front as found for other river plumes (e.g., O'Donnell et al., 1998; Bai et al., 2015). Drifter D1, the trajectory of which was close to Transect $\mathrm{C} 1$ between 122.3 and $122.7^{\circ} \mathrm{E}$, drifted from the inner boundary of the stratified zone $\left(\sim 122.3^{\circ} \mathrm{E}\right)$ to the surface plume front $\left(\sim 122.6^{\circ} \mathrm{E}\right)$ over $6-7 \mathrm{~h}$ during ebb tides and remained there for $5 \mathrm{~h}$ with velocities $<0.3 \mathrm{~m} \mathrm{~s}^{-1}$; thereafter the drifter moved continuously and rapidly (Figure 6A). This suggests the existence of convergence at the surface front that caused mass trapping and phytoplankton accumulation. On 

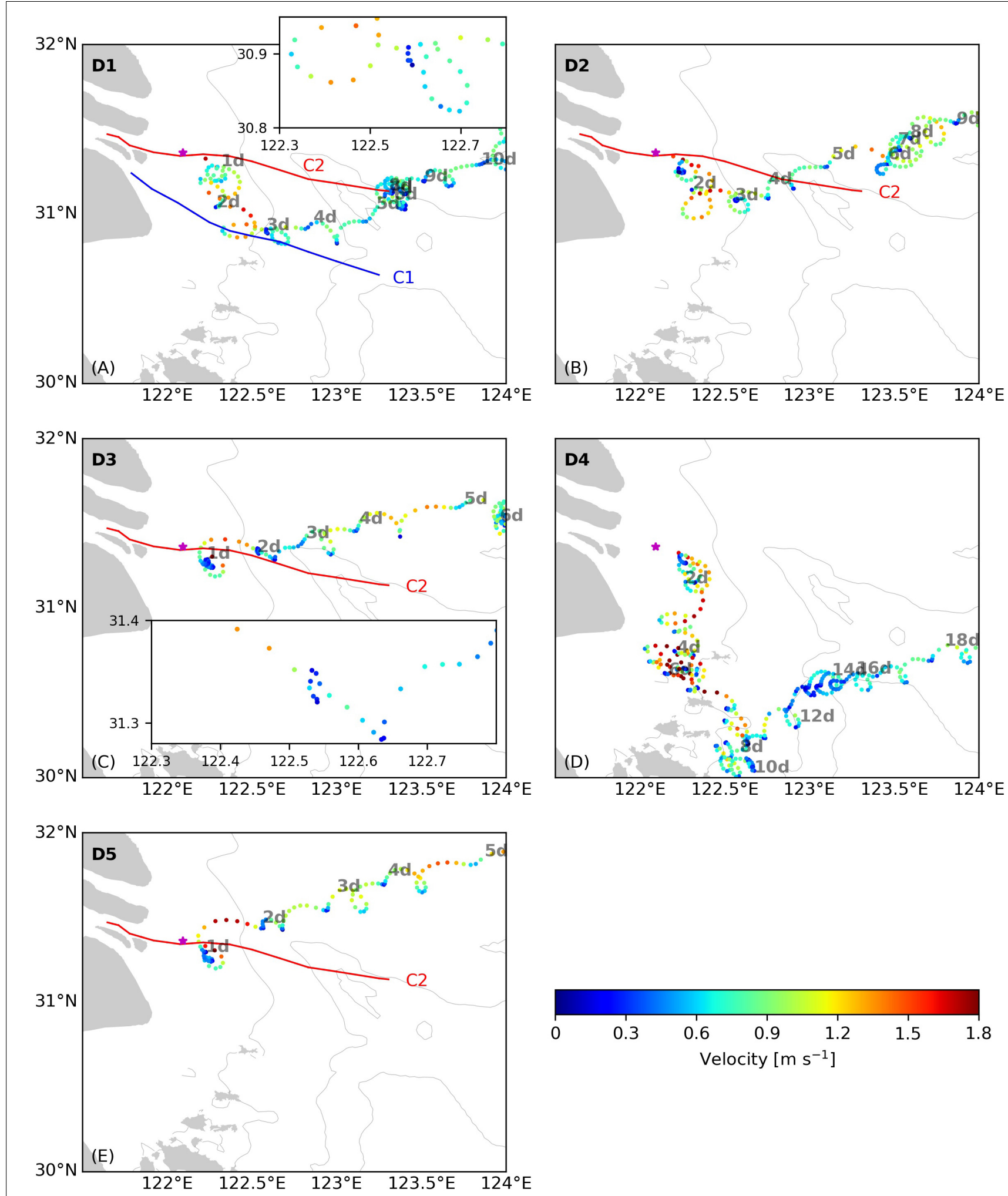

FIGURE 6 | Trajectories of Drifter (A) D1, (B) D2, (C) D3, (D) D4, and (E) D5 released near the Changjiang river mouth in the coastal area west of $124^{\circ} \mathrm{E}$. The elapsed time (in days) since the release are labeled along the trajectories. Color represents the velocity of the drifters. The thin, gray lines are the 20,50 , and $60 \mathrm{~m}$ isobaths. In (A,C), the trajectories in the section of $122.3-122.8^{\circ} \mathrm{E}$ are enlarged in an embedded panel to show the longer retention time of the drifters near $122.6^{\circ} \mathrm{E}$ (A) and in $122.5-122.6^{\circ} \mathrm{E}$ (C) which indicate surface flow convergence. 

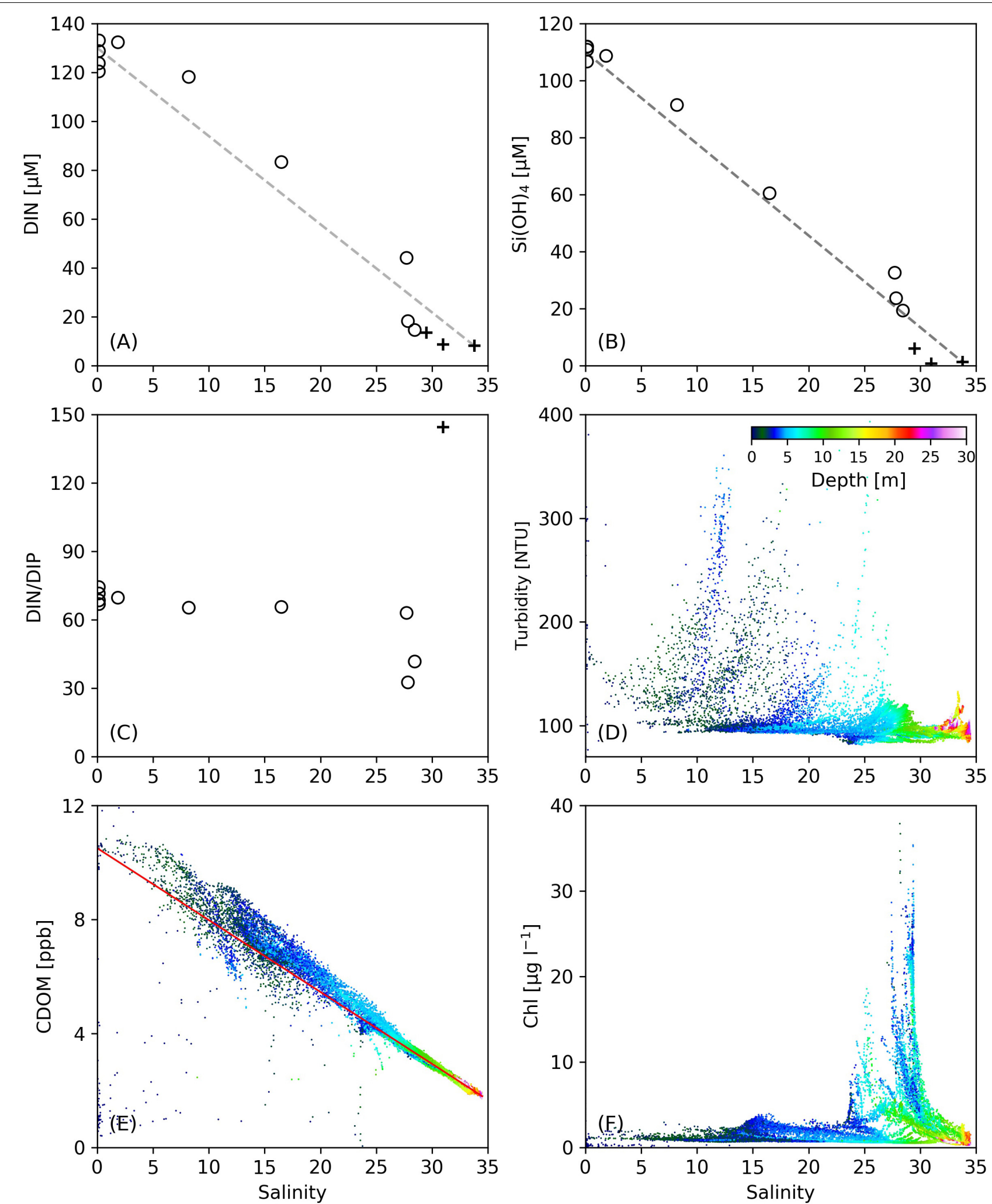

FIGURE 7 | The variations of (A) DIN, (B) Si(OH) 4 , (C) DIN/DIP, (D) turbidity, (E) CDOM, and (F) Chl concentrations as a function of salinity along Transect C1. In (A-C), open circles denote data from our cruise, and black crosses denote data from the open cruise. Missing black crosses at high salinity in (C) are due to low DIP values under the detection limit. 

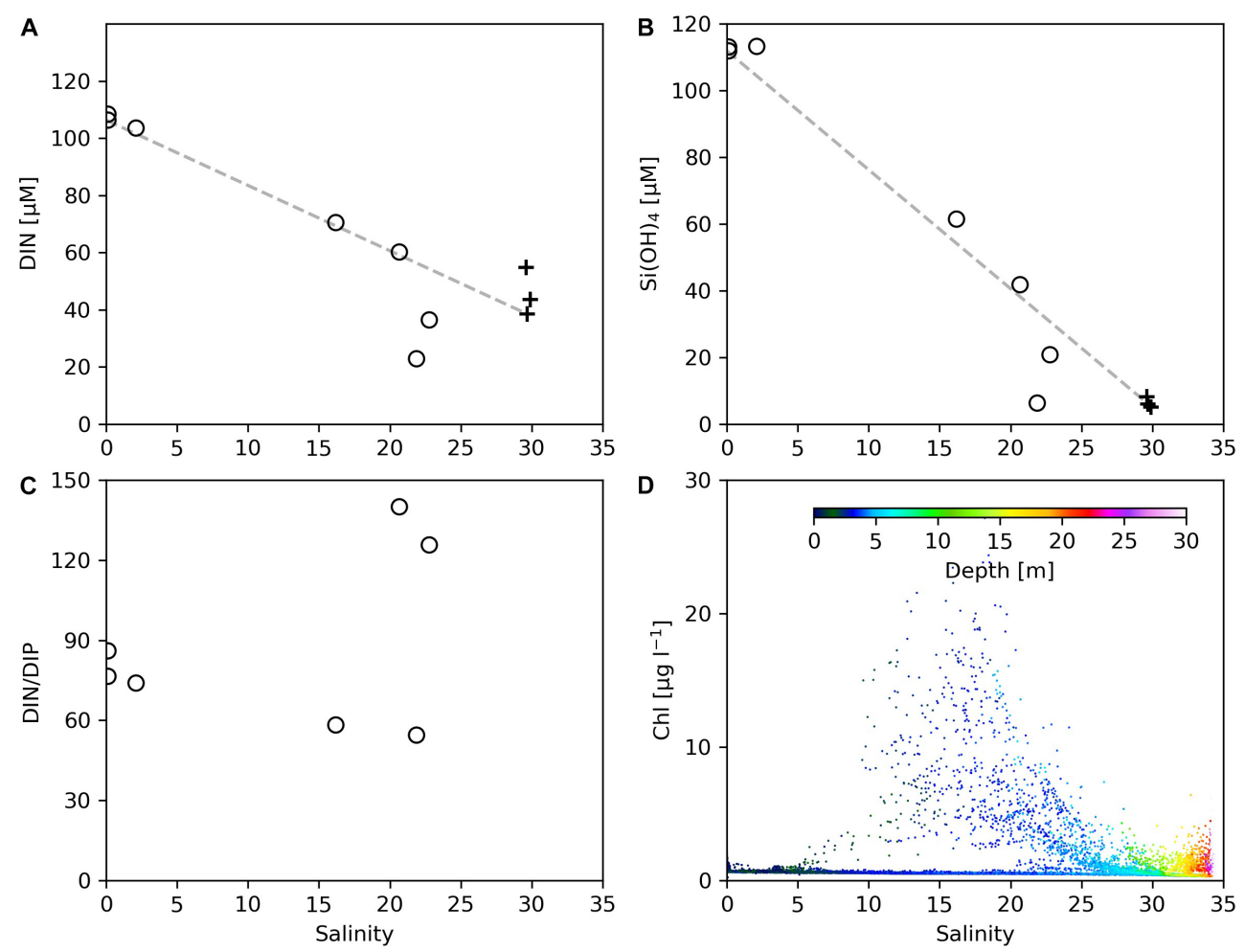

FIGURE 8 | The variations of (A) DIN, (B) Si $(\mathrm{OH})_{4}$, (C) DIN/DIP, and (D) Chl concentrations as a function of salinity on Transect C2. In (A-C), open circles denote data from our cruise, and black crosses denote data from the open research cruise. Missing black crosses at high salinity in (C) are due to low DIP values under the detection limit.

the other hand, downwelling arising from surface convergence increased the light penetration by $5 \mathrm{~m}$ (Figure 2G), which could enhance phytoplankton growth and contribute to the increased algal biomass (Smith and DeMaster, 1996) near the surface front. Long retention times under low velocities were also observed for Drifters D2, D3, and D5 near $122.5^{\circ} \mathrm{E}$ (Figure 6). In particular, the trajectory of D3 was close to Transect C2. The lingering of $\mathrm{D} 3$ for $8 \mathrm{~h}$ near $122.55^{\circ} \mathrm{E}$ indicates convergence associated with the plume surface front. While this front did not appear from the AESS measurements on C2 (Figure 4B), vertical mixing at the base of the plume was noted here (Figures 4B,C,E), which was possibly resulted from internal waves generated from the main plume front once exiting this area (see section "Potential Role of Internal Waves on the Retention Time of Phytoplankton and Algal Bloom"). It is noted that seaward of the surface front of $\mathrm{C} 2$ where the $\mathrm{Chl}$ concentration increased to above 10 $\mu \mathrm{g} \mathrm{L}-1$ (Figure 7F), the nitrate concentration (Figure 7A) fell below the conservative mixing line, indicating the role of surface front and phytoplankton bloom in genenrating the horizontal nutrient gradient.

\section{Potential Role of Internal Waves on the Retention Time of Phytoplankton and Algal Bloom}

On Transect C1, wave-like features were found seaward of the surface front of the Changjiang plume, together with the undulations of surface Chl concentrations and DO levels. Generation of internal waves by river plume fronts have been observed in other systems, such as the Columbia River (e.g., Nash and Moum, 2005; Kilcher and Nash, 2010), though the role of the plume-generated internal waves in phytoplankton production has not been extensively studied. These waves propagate toward the seaward side of the front and occur more frequently under upwelling favorable conditions than during downwelling (Jay et al., 2009). The wave-like signatures seaward of the surface front on $\mathrm{C} 1$ could be the manifestation of plumefront generated internal waves. The southerly winds in the

TABLE 1 | Values of the parameters used to calculate the Froude number Fr on different sections of Transect $\mathrm{C} 1$ and $\mathrm{C} 2$.

\begin{tabular}{lccccc}
\hline & \multicolumn{3}{c}{$\mathbf{C 1}$} & & \multicolumn{2}{c}{$\mathbf{C 2}$} \\
\cline { 2 - 3 } \cline { 5 - 6 } \cline { 5 - 6 } & $\begin{array}{c}\text { Inshore of } \\
\mathbf{1 2 2 . 5}^{\circ} \mathbf{E}\end{array}$ & $\begin{array}{c}\text { Offshore of } \\
\mathbf{1 2 2 . 5 ^ { \circ } \mathbf { E }}\end{array}$ & & $\begin{array}{c}\text { Inshore of } \\
\mathbf{1 2 2 . 5 ^ { \circ } \mathbf { E }}\end{array}$ & $\begin{array}{c}\text { Offshore of } \\
\mathbf{1 2 2 . 5 ^ { \circ } \mathbf { E }}\end{array}$ \\
\hline$u\left[\mathrm{~m} \mathrm{~s}^{-1}\right]$ & 1.2 & 0.7 & & 1.3 & 0.7 \\
$\Delta \rho\left[\mathrm{kg} \mathrm{m}^{-3}\right]$ & 10 & $10^{\mathrm{a}}$ & & 15 & $5-10^{\mathrm{a}}$ \\
$h[\mathrm{~m}]$ & 5 & $10^{\mathrm{b}}$ & & 4 & $10-15^{\mathrm{b}}$ \\
$\mathrm{Fr}$ & 1.7 & 0.7 & & 1.7 & $0.6-1.0$ \\
\hline
\end{tabular}

${ }^{a} \Delta \rho$ is the difference in density above and below the plume base. ${ }^{b} h$ is the plume thickness. 
Changjiang Estuary in summer are upwelling favorable and thus favor the generation of such waves.

Pan and Jay (2008) suggested that internal waves can remove up to $75 \%$ of the total energy of the Columbia River plume front, and change the flows in the plume from a supercritical, energetic state to a subcritical, less energetic state. Drifters D1, D2, D3 and D5 all showed dramatic reductions in the plume speed seaward of $122.5^{\circ} \mathrm{E}$ (Figure 6), where the ebb tidal velocity dropped from $1.2-1.7 \mathrm{~m} \mathrm{~s}^{-1}$ to below $0.9 \mathrm{~m} \mathrm{~s}^{-1}$. On Transect C1, the area seaward of $122.5^{\circ} \mathrm{E}$, which was the surface front location, coincided with where wave-like features appeared (Figure 2B). On C2, there were no wave-like patterns observed near the main front, but there was a zone between 122.5 and $122.9^{\circ} \mathrm{E}$ characterized by significant vertical mixing, which was possibly induced by waves passing through the area before the measurements were completed.

To investigate if the wave-like patterns and mixing features are related to the front-generated internal waves, we combined the drifter and hydrographic data to estimate the change in the flow state. Drifter D1 passed around the section between 122.3 and $122.8^{\circ} \mathrm{E}$ of Transect $\mathrm{C} 1$, and Drifter D3 passed around the section between 122.2 and $122.7^{\circ} \mathrm{E}$ of Transect $\mathrm{C} 2$. Though the passage of drifters and the AESS measurements did not occur on the same day, it has been found that the surface front location at different time (July 3 and 7) under different discharge and tidal conditions were only shifted by $20 \mathrm{~km}$, indicating that the hydrographic distributions do not change significantly over time. This allows us to use the velocity of Drifter D1 and D3, together with the thickness of the plume and the vertical density difference derived from the AESS measurements to estimate the change of $\mathrm{Fr}$ from inshore of the surface front to seaward of the front where internal waves were released, in order to determine if there was a transition of flow state related to energy removal by internal waves. The parameters used to calculate $\mathrm{Fr}$ in different sections of Transect $\mathrm{C} 1$ and $\mathrm{C} 2$ are listed in Table 1. For Transect C1, inshore of $122.5^{\circ} \mathrm{E}$ where the surface front in located, $F r$ was $\sim 1.7$, indicating that the flow was in a supercritical state. Seaward of the front to $122.8^{\circ} \mathrm{E}$ where wave features were observed, Fr dropped to 0.7. These results indicate that the observed wave signals were front-generated internal waves that transitioned the flow from supercritical to subcritical state. On Transect $\mathrm{C} 2$, inshore of $122.5^{\circ} \mathrm{E}$ where noticeable vertical mixing appeared, the estimated $\mathrm{Fr}$ was also $\sim 1.7$, indicative of supercritical flows. Seaward of $122.5^{\circ} \mathrm{E}$ the

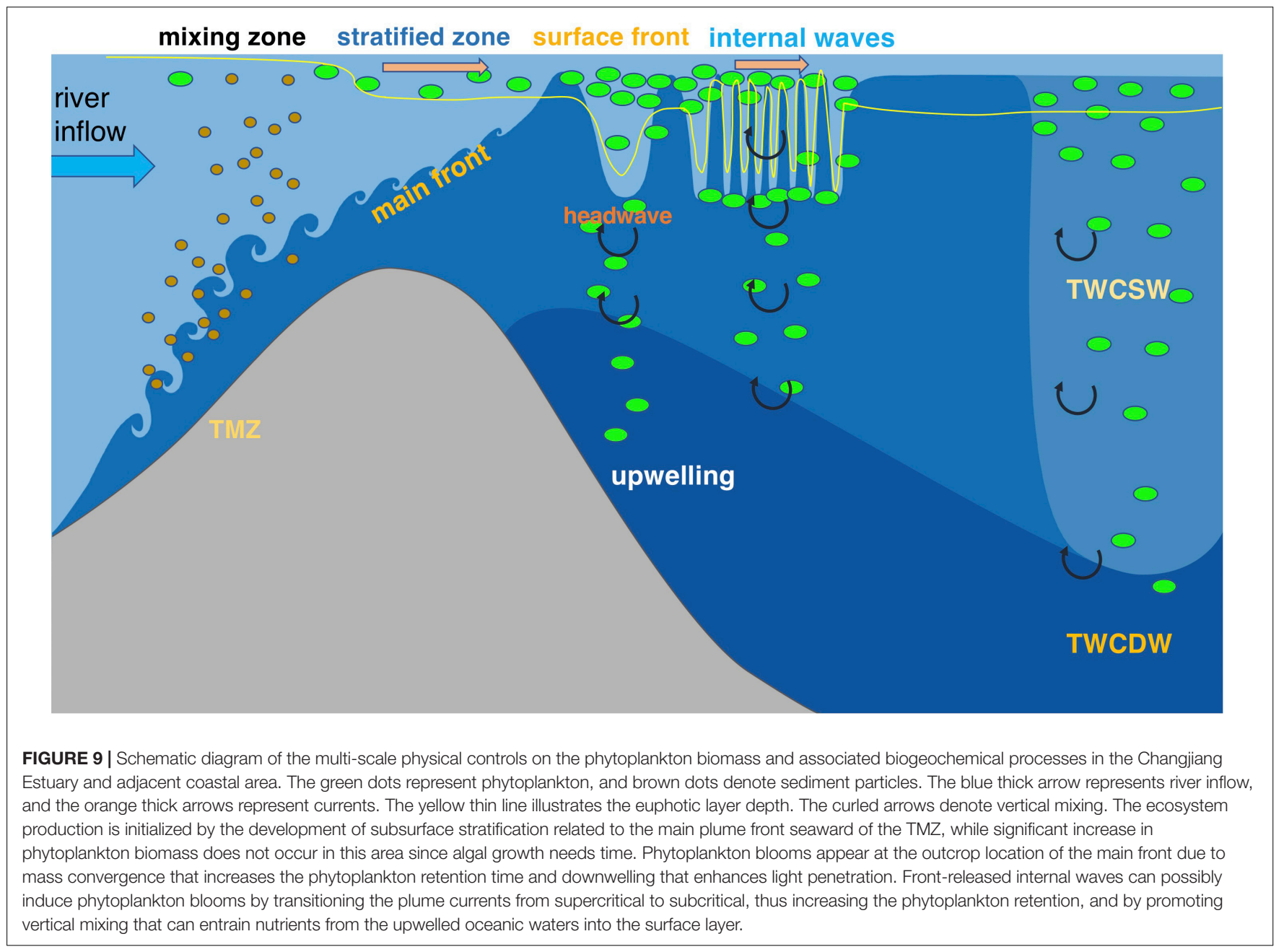


flow speed decreased to around $0.7 \mathrm{~m} \mathrm{~s}^{-1}$, and $\mathrm{Fr}$ dropped to $0.6-1$, suggesting the flow had changed to subcritical state, again indicating the role of internal waves in releasing energy from the plume currents. The appearance of vertical mixing between 122.5 and $122.9^{\circ} \mathrm{E}$ could be a footprint of the internal waves affecting this area, and the wide and diffusive surface front on C2 can be another consequence of internal waves that released energy from the front, as found by Jay et al. (2009) for the Columbia River plume.

On $\mathrm{C} 1$, the area dominated by waves coincided with the highest surface $\mathrm{Chl}$ concentration on the transect, and we believe that the enhanced biomass resulted from increased retention times of phytoplankton due to reduced plume momentum by internal waves. In addition, vertical mixing from internal waves can entrain nutrients from depth where relatively high nitrate concentrations $(10.7 \mu \mathrm{M})$ are found at $40 \mathrm{~m}$ (Jiang et al., 2020). On C2, upwelling existed in the zone between 122.4 and $123^{\circ} \mathrm{E}$, but phytoplankton blooms did not occur until vertical mixing occurred at $122.5^{\circ} \mathrm{E}$. This suggests that the vertical mixing from internal waves can supply additional nutrients from the upwelled TWCDW which in turn alleviates phosphorous stress. While upwelling has been widely recognized as an important physical means to stimulate phytoplankton growth in the Changjiang Estuary (Pei et al., 2009; Tseng et al., 2014; Liu and Gan, 2015), the role of smaller-scale features such as internal waves should not be ignored since they may be the factor that actually entrain nutrients from the upwelled water into the surface layer and define the onset location of the bloom area.

\section{Temporal Variation of the Physical and Biogeochemical Controls on Phytoplankton Growth and Accumulation}

The freshwater fronts in the salinity range of $0-15$ had moved considerably seaward on July 7 compared to that on July 3 (Figure 3), which can be associated with two factors. First, the region between 122 and $122.25^{\circ} \mathrm{E}$ was surveyed during flood tides on July 3, while on July 7, this area first experienced ebb tides and then flood tides. Second, the freshwater discharge had been increasing during our cruise from $\sim 56,000 \mathrm{~m} \mathrm{~s}^{-3}$ on July 3 to $\sim 69,000 \mathrm{~m} \mathrm{~s}^{-3}$ on July 7 , thus driving the freshwater further from the river mouth. On July 7, turbidity in the upper layer of the TMZ was much greater than that on July 3. This likely resulted from the spring and ebb tides during the survey on July 7 generating stronger mixing and bringing more suspended sediments into the upper layers (Wu et al., 2012).

On July 7 the Chl increase accompanying the strengthening in stratification was less than that on July 3, which we believe was a consequence of stronger ebb currents under the spring tide as well as larger freshwater discharge that caused greater advection of phytoplankton offshore. The outcropping location of this main front was shifted landward by approximately $20 \mathrm{~km}$ relative to that on July 3 , and the discrepancy in location is related to the different plume spreading rates under different tidal phases. Overall, while the locations of physical processes might change under different environmental conditions at different times (in fact the mixing and stratification regions were quite similar between July 3 and 7), the tight coupling between physical and biogeochemical processes, such as sediment suspension, light availability, and phytoplankton growth and distributions, was robust over time, suggesting the possibility of using physical parameters associated with the river plume to define and predict estuarine biogeochemical zones in the future.

\section{CONCLUSION}

Based on synoptic high-resolution measurements of physical and biological variables in the Changjiang Estuary and the adjacent coastal ocean, we demonstrate that spatial variation of phytoplankton biomass in an estuary is driven by a variety of dynamical processes on different scales associated with the river plume. These processes determine phytoplankton standing stocks by influencing irradiance availability, retention times and surface mass convergence, and nutrient concentrations. Multiple physical controls on biological processes in the Changjiang Estuary occur on varying time and space scales (Figure 9). Rapid development of strong subsurface stratification related to the main plume front is crucial for the initialization of phytoplankton biomass by reducing sediment suspension and improving light availability. While large nutrient gradients are observed in this strongly stratified zone, the biological removal makes a limited contribution to the nutrient gradients in this area, and reduction in nutrients is primarily driven by conservative mixing between fresh and saline waters. Phytoplankton blooms first appeared near the surface front of the plume, where the frontal convergence can cause phytoplankton accumulation and frontal downwelling can increase the light penetration depth. High phytoplankton biomass indicating algal growth also occurred in areas characterized by wave-like features or noticeable vertical mixing, resulting from front-generated internal waves that enhance phytoplankton biomass by retaining algae in the local area via flow energy release and/or by enhanced vertical nutrient exchange from regenerated nutrients in deep layers or from upwelled oceanic waters.

This study also suggests that while improved light conditions under reduced turbidity, upwelling and intrusion of an oceanic water mass with elevated nutrients all contribute to phytoplankton blooms, the small-scale features, such as frontal convergence and waves, determine their onset location. These findings may apply to other partially mixed and salt-wedge estuaries with strong freshwater fronts, such as the Amazon River, the Columbia River, and the Mississippi River Estuary, where the coupled physical-biological processes on small scale have less been investigated. These processes need to be assessed to fully understand the generation mechanisms and temporal evolution of phytoplankton blooms in the lower estuary and nearby coastal regions, and greater attention needs to be given to sub-mesoscale processes operating in estuaries.

\section{DATA AVAILABILITY STATEMENT}

The raw data supporting the conclusions of this article will be made available by the authors, without undue reservation, to any qualified researcher. 


\section{AUTHOR CONTRIBUTIONS}

$\mathrm{ZZ}$ and $\mathrm{MZ}$ designed the original ideas presented in this manuscript and coordinated the Changjiang Estuary research cruise. MZ conceived the project of the coupled physicalbiogeochemical processes in the Changjiang Estuary. ZZ, MZ, YZ, GZ, SJ, and YG collected the field measurements. ZZ, GZ, SJ, and YG worked on data analysis. ZZ wrote the original manuscript draft. RZ and WS participated in the manuscript preparation and improvement. All authors contributed to the article and approved the submitted version.

\section{FUNDING}

This work was funded by the National Science Foundation of China (Grant Nos. 41530960 and 41861134040) and Shanghai Jiao Tong University (Grant No. 2019QYB03 and the Oceanic Interdisciplinary Program No. SL2020ZD204).

\section{REFERENCES}

Bai, P., Gu, Y., Luo, L., Zhang, W., and Fan, K. (2015). Observation of the supercritical Pearl River plume front under the downwelling-favorable winds. Sci. China Earth Sci. 58, 2059-2066. doi: 10.1007/s11430-0155108-4

Chant, R. J. (2002). Secondary circulation in a region of flow curvature: Relationship with tidal forcing and river discharge. J. Geophys. Res 107:3131. doi: 10.1029/2001JC001082

Chant, R. J., Wilkin, J., Zhang, W., Choi, B., Hunter, E., Castelao, R., et al. (2008). Dispersal of the Hudson River Plume in the New York Bight: Synthesis of observational and numerical studies during LaTTE. Oceanogr 21, 148-161. doi: 10.5670/oceanog.2008.11

Chen, C., Zhu, J., Beardsley, R. C., and Franks, P. J. S. (2003). Physical-biological sources for dense algal blooms near the Changjiang River. Geophys. Res. Lett. 30:1515. doi: 10.1029/2002GL016391

Cloern, J. E. (1987). Turbidity as a control for phytoplankton biomass and productivity in estuaries. Cont. Shelf Res. 7, 1367-1381. doi: 10.1016/02784343(87)90042-2

Cloern, J. E. (1991). Tidal stirring and phytoplankton bloom dynamics in an estuary. J. Mar. Res. 49, 203-221. doi: 10.1357/00222409178496 8611

Cloern, J. E., Foster, S. Q., and Kleckner, A. E. (2014). Phytoplankton primary production in the world's estuarine-coastal ecosystems. Biogeosciences 11, 24772501. doi: 10.5194/bg-11-2477-2014

Cushman-Roison, B., and Beckers, J. (2011). Introduction to Geophysical Fluid Dynamics. Waltham: Academic Press. doi: 10.1016/B978-0-12-088759-0. 00001-8

Davis, R. (1985). Drifter observations of coastal surface currents during CODE: the method and descriptive view. J. Geophys. Res. 90, 4756-4772. doi: 10.1029/ JC090iC03p04756

Del Vecchio, R., and Blough, N. V. (2004). Spatial and seasonal distribution of chromophoric dissolved organic matter and dissolved organic carbon in the Middle Atlantic Bight. Mar. Chem. 89, 169-187. doi: 10.1016/j.marchem.2004. 02.027

DeMaster, D. J., Smith, W. O. Jr, Nelson, D. M., and Aller, J. Y. (1996). Biogeochemical processes in Amazon shelf waters: chemical distributions and uptake rates of silicon, carbon and nitrogen. Cont. Shelf Res. 16, 617-643. doi: 10.1016/0278-4343(95)00048-8

Desmit, X., Vanderborght, J.-P., Regnier, P., and Wollast, R. (2005). Control of phytoplankton production by physical forcing in a strongly tidal, well-mixed estuary. Biogeosciences 2, 205-218. doi: 10.5194/bg-2-2052005

\section{ACKNOWLEDGMENTS}

We thank the crews of the Zheyuke II for their hard work at sea and the scientists who joined the cruise to help in data collection. We also thank Dr. Hui Wu from East China Normal University for providing numerical simulations during the cruise planning. We thank Xiaolu Wang and Dr. Ying Wu (East China Normal University) for providing lab analysis of CDOM and turbidity, and Dr. Dinghui Shang (Tongji University) for providing lab analysis of chlorophyll-a. Nutrient data from the cruise funded by the National Science Foundation of China in July 2017 are appreciated.

\section{SUPPLEMENTARY MATERIAL}

The Supplementary Material for this article can be found online at: https://www.frontiersin.org/articles/10.3389/fmars. 2020.587539/full\#supplementary-material

Farmer, D. M., and Armi, L. (1986). Maximal two-layer exchange over a sill and through the combination of a sill and contraction with barotropic flow. J. Fluid Mech. 164, 53-76. doi: 10.1017/S002211208600246X

Fisher, T. R., Harding, L. W. Jr., Stanley, D. W., and Ward, L. G. (1988). Phvtoplankton nutrients and turbidity in the Chesapeake, Delaware and Hudson estuaries. Est. Coast. Shelf Sci. 27, 61-93. doi: 10.1016/0272-7714(88) 90032-7

Gao, L., Li, D., and Ishizaka, J. (2014). Stable isotope ratios of carbon and nitrogen in suspended organic matter: Seasonal and spatial dynamics along the Changjiang (Yangtze River) transport pathway. J. Geophys. Res. 119, 1717-1737. doi: 10.1002/2013JG002487

Geyer, W. R., Hill, P. S., and Kineke, G. C. (2004). The transport, transformation and dispersal of sediment by buoyant coastal flows. Cont. Shelf Res. 24, 927-949. doi: 10.1016/j.csr.2004.02.006

Guo, X., Cai, W.-J., Huang, W.-J., Wang, Y., Chen, F., Murrell, M. C., et al. (2012). Carbon dynamics and community production in the Mississippi River plume. Limnol. Oceanogr. 57, 1-17. doi: 10.4319/lo.2012.57.1.0001

Hansen, H. P., and Koroleff, F. (1999). "Determination of nutrients," in Methods of seawater analysis (3rd ed.), eds K. Grasshoff, K. Kremling, and M. Ehrhardt (Weinheim, Germany: Wiley-VCH).

Hickey, B. M., Kudela, R. M., Nash, J. D., Bruland, K. W., Peterson, W. T., MacCready, P., et al. (2010). River influences on shelf ecosystems: introduction and synthesis. J. Geophys. Res. 115:C00B17. doi: 10.1029/2009JC005452

Horner-Devine, A. R., Hetland, R. D., and MacDonald, D. G. (2015). Mixing and transport in coastal river plumes. Annu. Rev. Fluid Mech. 47, 569-594. doi: 10.1146/annurev-fluid-010313-141408

Jay, D. A., Pan, J., Orton, P. M., and Horner-Devine, A. R. (2009). Asymmetry of Columbia River tidal plume front. J. Mar. Syst. 78, 442-459. doi: 10.1016/j. jmarsys.2008.11.015

Jiang, S., Jin, J., Zhang, G., Chang, Y., Zhang, Z., Zhou, M., et al. (2020). Nitrate in the Changjiang Diluted Water: an isotopic evaluation on sources and reaction pathways. J. Oceanol. Limnol

Jiang, Z., Chen, J., Zhou, F., Shou, L., Chen, Q., Tao, B., et al. (2015). Controlling factors of summer phytoplankton community in the Changjiang (Yangtze River) Estuary and adjacent East China Sea shelf. Cont. Shelf Res. 101, 71-84. doi: 10.1016/j.csr.2015.04.009

Jurisa, J. T., and Chant, R. (2014). The coupled Hudson River estuarine-plume response to variable wind and river forcings. Ocean Dyn. 5, 771-784. doi: 10.1007/s10236-012-0527-7

Kilcher, L. F., and Nash, J. D. (2010). Structure and dynamics of the Columbia River tidal plume front. J. Geophys. Res. 115:C05S90. doi: 10.1029/2009JC006066

Lefèvre, N., Dias, F. J. S., Torres, A. R. Jr., Noriega, C., Araujo, M., Castro, A. C. L., et al. (2017). A source of CO2 to the atmosphere throughout the year in the 
Maranhense continental shelf $\left(2^{\circ} 30^{\prime} \mathrm{S}\right.$, Brazil). Cont. Shelf Res. 141, 38-50. doi: 10.1016/j.csr.2017.05.004

Lie, H.-J., Cho, C.-H., Lee, J.-H., and Lee, S. (2003). Structure and eastward extension of the Changjiang River plume in the East China Sea. J. Geophys. Res. 108:3077. doi: 10.1029/2001JC001194

Liu, X., Laws, E. A., Xie, Y., Wang, L., Lin, L., and Huang, B. (2019). Uncoupling of seasonal variations between phytoplankton chlorophyll a and production in the East China Sea. J. Geophys. Res. 124, 2169-8953. doi: 10.1029/2018JG004924

Liu, Z., and Gan, J. (2015). Upwelling induced by the frictional stress curl and vertical squeezing of the vortex tube over a submerged valley in the East China Sea. J. Geophys. Res. 120, 2571-2587. doi: 10.1002/2015JC010715

Lohrenz, S. E., Fahnenstiel, G. L., Redalje, D. G., Lang, G. A., Dagg, M. J., Whitledge, T. E., et al. (1999). Nutrients, irradiance, and mixing as factors regulating primary production in coastal waters impacted by the Mississippi River plume. Cont. Shelf Res. 19, 1113-1141. doi: 10.1016/S0278-4343(99) 00012-6

Lohrenz, S. E., Redalje, D., Cai, W.-J., Acker, J., and Dagg, M. (2008). A retrospective analysis of nutrients and phytoplankton productivity in the Mississippi River plume. Cont. ShelfRes. 28, 1466-1475. doi: 10.1016/j.csr.2007. 06.019

Lucas, L. V., Koseff, J. R., Monismith, S. G., Cloern, J. E., and Thompson, J. K. (1999). Processes governing phytoplankton blooms in estuaries, II. The role of horizontal transport. Mar. Ecol. Prog. Ser. 187, 17-30. doi: 10.3354/meps187017

McSweeney, J. M., Chant, R. J., Wilkin, R. J., and Sommerfield, C. K. (2017). Suspended-sediment impacts on light-limited productivity in the Delaware Estuary. Estuar. Coast. 40, 977-993. doi: 10.1007/s12237-016-0200-3

Moline, M. A., Fraser, T. K., Chant, R. J., Glenn, S., Jacoby, C. A., Reinfelder, J. R., et al. (2008). Biological responses in a dynamic buoyant river plume. Oceanography 21, 70-89. doi: 10.5670/oceanog.2008.06

Nash, J. D., and Moum, J. N. (2005). River plumes as a source of large-amplitude internal waves in the coastal ocean. Nature 437, 400-403. doi: 10.1038/ nature 03936

O'Donnell, J., Marmorino, G. O., and Trump, C. L. (1998). Convergence and downwelling at a river plume front. J. Phys. Oceanogr. 28, 1481-1495. doi: 10.1175/1520-0485(1998)028<1481:CADAAR > 2.0.CO;2

Pan, J., and Jay, D. A. (2008). Dynamic characteristics and horizontal transports of internal solitons generated at the Columbia River plume front. Cont. Shelf Res. 29, 252-262. doi: 10.1016/j.csr.2008.01.002

Parsons, T. R., Maita, Y., and Lalli, C. M. (1984). A manual of Chemical and Biological Methods of Seawater Analysis. Oxford: Pergamon Press, 173.

Pei, S., Shen, Z., and Laws, E. A. (2009). Nutrient Dynamics in the Upwelling Area of Changjiang (Yangtze River) Estuary. J. Coast. Res. 25, 569-580. doi: 10.2112/07-0948.1

Schofield, O., Moline, M., Cahill, B., Frazer, T., Kahl, A., Reinfelder, J., et al. (2013). Phytoplankton productivity in a turbid buoyant coastal plume. Cont. Shelf Res. 63, S138-S148. doi: 10.1016/j.csr.2013. 02.005

Schubel, J. R. (1968). Turbidity maximum in the northern Chesapeake Bay. Science 161, 1013-1015. doi: 10.1126/science.161.3845.1013

Shen, H., Mao, Z., and Zhu, J. Eds (2003). Saltwater Intrusion in the Changjiang Estuary. Beijing: China Ocean.

Simpson, J., Brown, H. J., Matthews, J., and Allen, G. (1990). Tidal straining, density currents, and stirring in the control of estuarine stratification. Estuaries 13, 125-132. doi: $10.2307 / 1351581$

Smith, W. O. Jr., and DeMaster, D. J. (1996). Phytoplankton biomass and productivity in the Amazon River Plume: correlation with seasonal river discharge. Cont. Shelf Res. 16, 291-319. doi: 10.1016/0278-4343(95) 00007-N
Spahn, E. Y., Horner-Devine, A. R., Nash, J. D., Jay, D. A., and Kilcher, L. (2009). Particle resuspension in the Columbia River plume near field. J. Geophys. Res. 114:C00B14. doi: 10.1029/2008JC004986

Tang, X., and Wang, F. (2004). Analyses on hydrographic structure in the Changjiang River estuary adjacent waters in summer and winter. Stud. Mar. Sin. 46, 42-66.

Tseng, Y. F., Lin, J., Dai, M., and Kao, S. J. (2014). Joint effect of freshwater plume and coastal upwelling on phytoplankton growth off the Changjiang River. Biogeosci. Discuss. 10, 10363-10397. doi: 10.5194/bgd-10-10363-2013

Wang, Y., Wu, H., Lin, J., Zhu, J., Zhang, W., and Li, C. (2019). Phytoplankton blooms off a high turbidity estuary: A case study in the Changjiang River Estuary. J. Geophys. Res. 124, 8036-8059. . https://doi.org/10.1029/ 2019JC015343,

Wright, L. D., and Coleman, J. M. (1971). Effluent expansion and interfacial mixing in the presence of a salt wedge, Mississippi River delta. J. Geophys. Res. 76, 8649-8661. doi: 10.1029/JC076i036p08649

$\mathrm{Wu}, \mathrm{H}$. (2015). Cross-shelf penetrating fronts: A response of buoyant coastal water to ambient pycnocline undulation. J. Geophys. Res. 120, 5101-5119. doi: 10. 1002/2014JC010686

Wu, J., Liu, J. T., and Wang, X. (2012). Sediment trapping of turbidity maxima in the Changjiang Estuary. Mar. Geol. 30, 14-25. doi: 10.1016/j.margeo.2012.02. 011

Xu, Y., Cahill, B., Wilkin, J., and Schofield, O. (2013). Role of wind in regulating phytoplankton blooms on the Mid-Atlantic Bight. Cont. Shelf Res. 63, S26-S35. doi: 10.1016/j.csr.2012.09.011

Xuan, J.-L., Huang, D., Zhou, F., Zhu, X.-H., and Fan, X. (2012). The role of wind on the detachment of low salinity water in the Changjiang Estuary in summer. J. Geophys. Res. 117:C10004. doi: 10.1029/2012JC008121

Yang, D., Yin, B., Sun, J., and Zhang, Y. (2013). Numerical study on the origins and the forcing mechanism of the phosphate in upwelling areas off the coast of Zhejiang province. China in summer. J. Mar. Syst. 12, 1-18. doi: 10.1016/j. jmarsys.2013.04.002

Zhang, J., Liu, S., Ren, J., Wu, Y., and Zhang, G. (2007). Nutrient gradients from the eutrophic Changjiang (Yangtze River) Estuary to the oligotrophic Kuroshio waters and re-evaluation of budgets for the East China Sea Shelf. J. Mar. Syst. 74, 449-478. doi: 10.1016/j.pocean.2007.04.019

Zhang, Q., Liu, H., Qin, S., Yang, D., and Liu, Z. (2014). The study on seasonal characteristics of water masses in the western East China Sea shelf area. Acta. Oceanol. Sin. 33, 64-74. doi: 10.1007/s13131-014-0556-9

Zhou, F., Chai, F., Huang, D., Xue, H., Chen, J., Xiu, P., et al. (2017). Investigation of hypoxia off the Changjiang Estuary using a coupled model of ROMSCoSiNE. Prog. Oceanogr. 159, 237-254. doi: 10.1016/j.pocean.2017.10.008

Zhu, Z., Ng, W.-M., Liu, S., Zhang, J., Chen, J.-C., and Wu, Y. (2009). Estuarine phytoplankton dynamics and shift of limiting factors: A study in the Changjiang (Yangtze River) Estuary and adjacent area. Estuar. Coast. Shelf Sci. 84, 393-401. doi: 10.1016/j.ecss.2009.07.005

Conflict of Interest: The authors declare that the research was conducted in the absence of any commercial or financial relationships that could be construed as a potential conflict of interest.

Copyright $\odot 2020$ Zhang, Zhou, Zhong, Zhang, Jiang, Gao, Zhang and Smith. This is an open-access article distributed under the terms of the Creative Commons Attribution License (CC BY). The use, distribution or reproduction in other forums is permitted, provided the original author(s) and the copyright owner(s) are credited and that the original publication in this journal is cited, in accordance with accepted academic practice. No use, distribution or reproduction is permitted which does not comply with these terms. 